\title{
Perencanaan Arsitektur Enterprise Klinik Inti Sehat Medika dengan TOGAF ADM
}

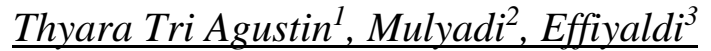 \\ Sistem Informasi, Fakultas Ilmu Komputer, Universitas Dinamika Bangsa \\ Jalan Jendral Sudirman Thehok, Jambi, Indonesia \\ thyaratriagustin@gmail.com ${ }^{1}$,mulyadi@unama.ac.id ${ }^{2}$,yaldi67@gmail.com ${ }^{3}$
}

\begin{abstract}
The health services available at the Inti Sehat Medika Clinic include general poly, dental poly, obstetrics poly, and laboratory. Services have not run optimally because the activities that occur between units have not been supported by information services from well-integrated systems. This study aims to map out an enterprise architecture in order to improve services to organization stakeholder. This research uses TOGAF ADM methodology with an object oriented approach. This method emphasizes on four phases, specifically the determination of the information system architecture vision, business architecture modeling, information system architecture modeling and technology architecture modeling. This study produces an information system architecture blueprint in the form of application entrants for every sub-organization which are decided founded on the urgency level of desires, the results of the blueprint can be used as a orientation in the improvement of information systems so that the implementation is more focused and does not affect with the performance of the information system either current or being constructed in an organization to realize its planned goals.
\end{abstract}

Keywords : enterprise architecture, togaf adm, enterprise architecture blueprint, information system.

\begin{abstract}
Abstrak
Pelayanan kesehatan yang tersedia pada Klinik Inti Sehat Medika antara lain poli umum, poli gigi, poli kandungan, dan laboratorium. Pelayanan belum berjalan secara optimal karena aktifitas yang terjadi antar bagian belum didukung dengan layanan informasi dari sistem yang terintegrasi dengan baik. Penelitian ini bertujuan merancang arsitektur enterprise untuk meningkatkan pelayanan bagi stakeholder organisasi. Penelitian ini menggunakan metodologi TOGAF ADM dengan pendekatan berorientasi objek. Metode ini ditekankan pada empat langkah, yaitu penetapan visi arsitektur sistem informasi, pemodelan arsitektur bisnis, pemodelan arsitektur sistem informasi dan pemodelan arsitektur teknologi. Hasil penelitian ini adalah suatu cetak biru arsitektur sistem informasi berupa usulan-usulan aplikasi untuk setiap sub organisasi yang disusun berdasarkan tingkat prioritas kebutuhan, yang dapat digunakan sebagai acuan dalam pengembangan sistem informasi, sehingga lebih terarah dalam implementasi dan tidak mengganggu kinerja sistem informasi, baik yang sudah ada maupun yang sedang dibangun pada suatu organisasi untuk mencapai tujuan strategisnya.
\end{abstract}

Kata kunci : arsitektur enterprise, togaf adm, blueprint arsitektur enterprise, sistem informasi.

\section{Pendahuluan}

Klinik Inti Sehat Medika merupakan instansi yang memberikan layanan kesehatan bagi masyarakat yang berlokasi di Jalan JL Hos Cokroaminoto, No. 92-92A, Simpang Kawat, Kota Jambi. Layanan pada klinik antara lain poli umum, poli kandungan, poli gigi dan laboratorium. Aktifitas yang berjalan dalam belum sepenuhnya terkoordinasi dengan baik dan belum ditunjang penggunakan teknologi informasi yang optimal sehingga menyebabkan informasi yang dihasilkan masih rentan dengan kesalahan dan layanan bagi pasien memakan waktu yang lebih lama, sedangkan layanan dibidang kesehatan merupakan layanan yang urgen dan membutuhkan tingkat keakuratan informasi yang sangat tinggi, sehingga dibutuhkan dukungan sistem informasi terintegrasi guna meningkatkan pelayanan. sistem informasi terpadu mendukung efisiensi proses bisnis dengan biaya akan lebih rendah dibandingkan dengan penggunaan sistem informasi yang belum terintegrasi [1].

Untuk membangun sebuah sistem bukan suatu perkara yang mudah. Banyak sistem yang gagal karena dibangun untuk hal yang luar biasa tanpa memahami dengan jelas bagaimana sistem akan mendukung tujuan organisasi, meningkatkan informasi, mengintegrasikan dengan sistem informasi lain untuk memberikan nilai tambah [2]. Enterprise Architecture (EA) merupakan sebuah pola pikir untuk membuat perencanaan, perancangan dan pengelolaan sistem informasi guna meningkatkan efektifitas layanan. EA merupakan alat konseptual yang membantu organisasi memahami struktur dan proses bisnis yang digunakan untuk perubahan bisnis dan teknologi [3]. EA dapat menjamin kesesuaian strategi bisnis terhadap teknologi informasi organisasi sehingga kebutuhan bisnis dapat terpadu dengan dukungan TI perusahaan [4]. EA merupakan saran yang cukup baik karena semakin bertambahnya kebutuhan 
perusahaan terhadap fungsi dan proses bisnis yang sedang berjalan sehingga perlu diselaraskan antara kebutuhan bisnis, aplikasi, data, maupun teknologi [5].

Perencanaan arsitektur enterprise membutuhkan framework yang tepat. TOGAF merupakan framework paling sesuai untuk digunakan pada organisasi yang belum memiliki EA dan digunakan untuk untuk pengembangan EA yang mudah dan jelas [6]. Architecture Development Method (ADM) adalah bagian dari TOGAF yang menggambarkan secara rinci bagaimana menetapkan suatu EA secara khusus sesuai dengan kepentingan bisnisnya. ADM adalah pendekatan bertahap - iteratif dan inkremental - untuk mengembangkan arsitektur dan memberikan nilai bisnis dengan menyadari apa yang dirancang [3].

Pada penelitian [7] penerapan TOGAF ADM menunjukkan langkah terarah dan dapat disesuaikan dengan kepentingan organisasi dalam merancang arsitektur bisnis, arsitektur informasi, arsitektur data, dan arsitektur aplikasi yang mendukung sistem, dan menghasilkan cetak biru arsitektur yang harus dapat diterima oleh pihak Puskesmas Mempawah untuk dipertimbangkan bagi seluruh stakeholder agar dapat diimplementasikan. Penelitian lainnya [8] menggunakan framework yang sama menghasilkan EA sistem informasi yang selaras dengan visi misi dan berbasis web yang terpadu bagi semua unit pada Puskesmas Cimalaka. Pada penelitian [9], penggunaan framework ini cukup mudah dalam menetapkan alat bantu analisis dengan menyesuaikan kebutuhan analisis di setiap tahapan kerja TOGAF. Penelitian menghasilkan cetak biru arsitektur yang dapat diterima oleh pihak Puskesmas Siantan Hilir sebagai pertimbangan untuk bagi stakeholder.

Tujuan penelitian ini adalah untuk membuat perencanaan EA bagi Klinik Inti Sehat Medika menggunakan TOGAF ADM guna menghasilkan cetak biru pengembangan arstitektur SI/TI yang terintegrasi. Framework TOGAF ADM memberikan petunjuk dan arahan kepada organisasi dalam membuat perencanaan, perancangan, serta pengimplementasian sistem informasi pada organisasinya [10].

\section{Metodologi}

Sebagai acuan untuk memaksimalkan potensi kinerja SI/TI di masa mendatang, maka dilakukan pemetaan dan pengembangan arsitektur TI melalui tahapan yaitu tahap preliminary, tahap architecture vision, tahap business architecture, tahap information systems architectures, dan technology architecture [11].

a. Fase Preliminary: Framework and Principles

Fase ini merupakan tahap persiapan organisasi untuk melakukan pekerjaan arsitektur dengan menyesuaikan kerangka kerja TOGAF untuk tugas yang ada didalam organisasi, sesuai kebutuhan bisnis untuk arsitektur yang yang baru, pendefinisian kerangka kerja dan metodologi yang detail serta prinsip - prinsip yang dipakai pada pengembangan EA.

b. Fase A : Architecture Vision

Pada tahap ini dilakukan pendefinisian profil organisasi, visi arsitektur, tujuan bisnis (business goal), sasaran bisnis (business objective), ruang lingkup (scope), dan stakeholder

c. Fase B : Business Architecture

Pada tahap ini menentukan sudut pandang arsitektur yang sejalan dengan bisnis dan menentukan teknik dan tools yang tepat, lalu memaparkan arsitektur bisnis yang ada dan sasaran pengembangannya. Hal ini bisa ditafsirkan sebagai semua hal yang non-IT, tetapi relevan dengan TI.

d. Fase C : Information Systems Architectures

Pada tahap ini target pengembangan arsitektur yaitu pada data dan domain aplikasi, seperti menentukan tipe dan sumber data yang diperlukan untuk mendukung bisnis menggunakan cara yang dimengerti oleh pemangku kepentingan, menentukan jenis aplikasi yang dibutuhkan oleh sistem untuk memproses data dan mendukung bisnis.

e. Fase D : Technology Architecture

Untuk pengembangan arsitektur teknologi dimulai dari penentuan usulan jenis teknologi yang dibutuhkan, meliputi perangkat lunak dan perangkat keras dengan memepertimbangkan alternatif-alternatif yang dibutuhkan dalam pemilihan teknologi.

\section{Pembahasan}

\subsection{Preliminary Phase (Tahap Persiapan)}

Langkah-langkah yang diambil dalam tahap persiapan ini adalah menganalisa ruang lingkup enterprise organisasi. Arsitektur enterprise di Klinik Inti Sehat Medika memiliki aktivitas utama pendaftaran Pasien, Poli Rawat Jalan, Laboratorium, Instalasi Farmasi, aktivitas pendukung Manajemen Keuangan, Manajemen Kepegawaian, Manajemen Sarana Prasarana. Pendefinisian area bisnis Klinik Inti Sehat Medika digambarkan pada Gambar 1 dibawah ini dengan menggunakan value chain. 


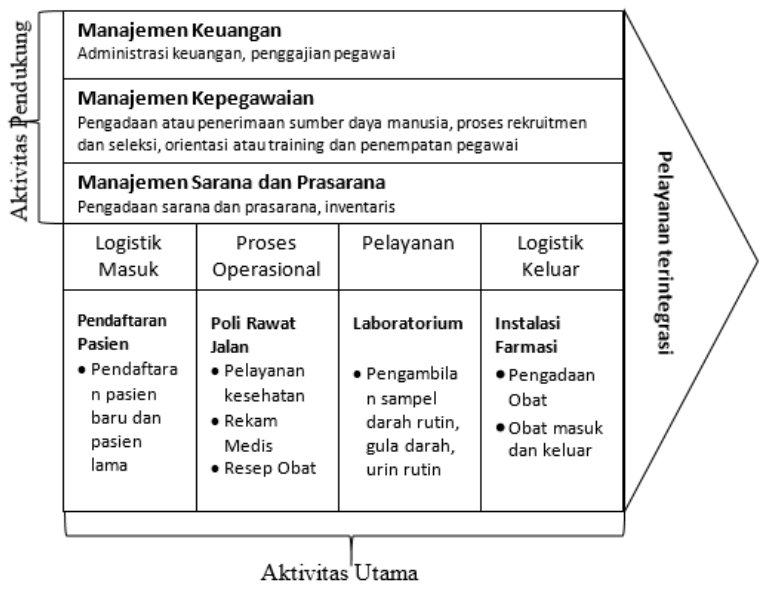

Gambar 1. Value Chain Klinik Inti Sehat Medika

\subsection{Requirement Management}

Pengembangan sistem informasi Klinik Inti Sehat Medika harus sesuai dengan kebutuhan untuk mencapai suatu tujuan organisasi. Skenario bisnis menjadi sumber daya yang harus dikembangkan pada tahap ini. Skenario tersebut harus mencakup core business, business process, dan organization issue.

a. Core Business

Core business atau bisnis utama di Klinik Inti Sehat Medika dalam pelaksanaannya juga memerlukan hal-hal sebagai berikut:

1. Sistem informasi yang dapat mendukung kebutuhan pasien, rekam medis, obat, dan keuangan.

2 Teknologi informasi yang mendukung semua kegiatan klinik

3. Membuat Standard Operating Procedure (SOP) yang dapat menunjang pencapain pelayanan maksimal dalam segala bidang organisasi bisnis.

b. Business process

Proses bisnis merupakan serangkaian kegiatan yang dilakukan oleh organisasi. Salah satu Tools yang digunakan untuk menggambarkan aliran kegiatan proses bisnis adalah diagram Swimline. Setiap proses bisnis pada klinik akan digambarkan dengan menggnakan diagram Swimline yaitu :

1. Proses Pendaftaran Pasien Baru

Proses pendaftaran pasien dimulai dari pengisian formulir hingga pencetakan kartu pasien yang dapat digunakan pasien untuk melakukan pendaftaran rawat jalan

2. Proses Poli Rawat Jalan

Proses pada poli rawat jalan di Klinik Inti Sehat Medika dilaksanakan mulai dari pendaftaran rawat jalan, pemeriksaan oleh dokter serta tindakan pengobatan yang diberikan terhadap pasien.

3. Proses Laboratorium

Proses di laboratorium dilaksanakan setelah petugas menerima surat permintaan pemeriksaan laboratorium dari dokter, selanjutnya melakukan pengambilan sampel dan memprosesnya. Hasil pemeriksaan dinyatakan berupa surat yang dikembalikan kepada dokter yang melakukan pemeriksaan. Berdasarkan hasilnya, dokter melakukan tindakan pengobatan sebagaimana yang telah dijabarkan pada gambar sebelumnya.

4. Proses Instalasi Farmasi

Proses pada instalasi farmasi adalah menyipkan obat setelah menerima resep dokter, selanjutnya menyerahkan kepada pasien dengan terlebih dahulu menjelaskan penggunaan obat. Untuk menstabilkan stok dilakukan pengadaan dan pelaporan kepada pimpinan.

5. Proses Manajemen Keuangan

Proses ini diawali dengan menginputkan seluruh biaya yang dikeluarkan untuk kemudian disusun laporan keuangannya untuk diperiksa oleh penanggung jawab. Selanjutnya laporan keuangan diserahkan kepada pimpinan

6. Proses Manajemen Kepegawaian

Proses pada manajemen kepegawaian antara lain menginputkan data karyawan, kehadiran, pengaturan shift kerja dan mempersiapkan laporan kepegawaian untuk diperiksa oleh penanggung jawab, selanjutnya laporan diserahkan kepada pimpinan.

7. Proses Manajemen Sarana dan Prasarana

Proses pada bagian ini antara lain menginputkan data sarana dan prasarana, perencanaan dan pengadaan, menyusun laporan sarana dan prasarana untuk diperiksa oleh penanggung jawab, selanjutnya diserahkan kepada pimpinan. 
c. Organization Issue

Berdasarkan hasil observasi dan analisa yang dilakukan terhadap proses bisnis di Klinik Inti Sehat Medika, maka diperoleh gambaran permasalahan yang dialami oleh Klinik tersebut. Permasalahan tersebut dapat dijelaskan pada Tabel 1 dibawah ini.

Tabel 1. Permasalahan Klinik Inti Sehat Medika

\begin{tabular}{|c|c|c|}
\hline No. & Aktivitas bisnis & Permasalahan \\
\hline 1. & Pendaftaran Pasien & $\begin{array}{l}\text { - Pendaftaran pasien membutuhkan waktu yang lama karna harus } \\
\text { mencari data rekam medis secara manual } \\
\text { - Data pasien masih harus diantarakan oleh perawat ke poli. }\end{array}$ \\
\hline 2. & Poli Rawat Jalan & $\begin{array}{l}\text { - Proses penyampaian resep masih menggunakan kertas dan } \\
\text { diantarkan oleh perawat ke instalasi farmasi. } \\
\text { - Rekam medis belum terdata ke database } \\
\text { - Penghitungan jasa dokter belum efisien. }\end{array}$ \\
\hline 3. & Laboratorium & $\begin{array}{l}\text { - Penulisan nomor labor yang masih harus di tulis tangan } \\
\text { menyebabkan kertas hilang dan susah untuk dicari } \\
\text { - Pengarsipan hasil labor yang masih di tulis tangan dan di arsip dalam } \\
\text { agenda membuat pencarian data susah dan lama untuk dicari }\end{array}$ \\
\hline 4. & Instalasi Farmasi & $\begin{array}{l}\text { - Pendataan keluar masuk obat sulit untuk dilakukan. } \\
\text { - Jumlah aset obat sulit untuk diketahui } \\
\text { - Tidak mempunyai resep online } \\
\text { - Ketidak sesuaian faktur yg dikeluarkan dari distributor dengan faktur } \\
\text { yang diterima oleh klinik }\end{array}$ \\
\hline 5. & $\begin{array}{l}\text { Manajemen } \\
\text { Keuangan }\end{array}$ & - Administrasi dan pelaporan harian dan bulanan tidak efisien. \\
\hline 6. & $\begin{array}{l}\text { Manajemen } \\
\text { Kepegawaian }\end{array}$ & - Pendataan jadwal dokter dan tenaga medis belum dapat diketahui. \\
\hline 7. & $\begin{array}{l}\text { Manajemen Sarana \& } \\
\text { Prasarana }\end{array}$ & - Pendataan seluruh sarana dan prasarana yang telah terpakai \\
\hline
\end{tabular}

Untuk mengatasi beberapa permasalahan yang telah disebutkan pada Tabel 1, Solusi permasalahan yang ditawarkan dikelompokan berdasarakan nama aktivitas bisnis dan perbaikan yang ditinjau dari solusi sistem informasi yang fokus pada pengembangan aplikasi guna mendukung proses aktivitas bisnis. Solusi permasalahan tersebut dapat disajikan dalam Tabel 2 dibawah ini:

Tabel 2. Solusi Bisnis Terhadap Permasalahan Organisasi

\begin{tabular}{lll}
\hline No. & Permasalahan & Sasaran Perbaikan \\
\hline 1. & Pendaftaran pasien membutuhkan waktu yang & Memanfaatkan sistem informasi dan database \\
lama karna harus mencari data rekam medis pasien. \\
secara manual
\end{tabular}

2. Data pasien masih harus diantarakan oleh Penggunaan sistem paperless dari pendaftaran ke perawat ke poli. tiap-tiap poli.

3. Proses penyampaian resep masih menggunakan Penggunaan sistem paperless dari poli ke apotek kertas dan diantarkan oleh perawat ke Instalasi farmasi.

4. Rekam medis belum terdata ke database.

Pemanfaatan sistem informasi pendataan rekam medis.

5. Penghitungan jasa dokter belum efisien.

Penghitungan jasa dokter yang terhubung ke sistem pendaftaran.

7. Pengarsipan hasil labor yang masih di tulis tangan dan di arsip dalam buku membuat Pemanfaatan sistem informasi database pencarian data susah dan lama. pengarsipan data. 
8. Pendataan keluar masuk obat sulit untuk Pemanfaatan sistem farmasi dengan maksimal. dilakukan.

\subsection{Architecture Vision}

Tahapan ini bertujuan untuk mengidentifikasi kebutuhan informasi untuk perancangan arsitektur enterprise. Klinik Inti Sehat Medika memiliki 17 karyawan terdiri dari 7 orang dokter umum, 1 orang dokter spesialis gigi, 1 orang admin, 4 orang perawat, 1 orang apoteker, 2 orang asisten apoteker dan 1 orang analis laboratorium.

Visi yang ingin dicapai adalah menjadikan fasilitator kesehatan tingkat pratama yang dapat melayani dengan cepat dan tanggap terhadap masyarakat tentunya lingkungan sekitar dan mampu memberikan pelayanan yang berkualitas dan nyaman bagi masyarakat umum. Misi yang diemban antara lain memberikan pelayanan kesehatan yang bermutu dan terjangkau, membantu pemerintah menjalani program kesehatan dalam upaya meningkatkan derajat kesehatan masyarakat dan menciptakan suasana kerja yang dilandasi oleh rasa kekeluargaan.

\subsection{Business Architecture}

Tahapan ini bertujuan untuk mengidentifikasi hubungan antara proses bisnis dengan stakeholder organisasi. Fungsi bisnis pada Klinik Inti Sehat Medika terdiri dari proses bisnis utama antara lain Pendaftaran Pasien (PP), Poli Rawat Jalan (PRJ), Laboratorium (L) dan Instalasi Farmasi (IF), sedangkan proses bisnis pendukung terdiri dari Manajemen Keuangan (MK), Manajemen Kepegawaian (MKEP), dan Manajemen Sarana \& Prasarana (MSP).

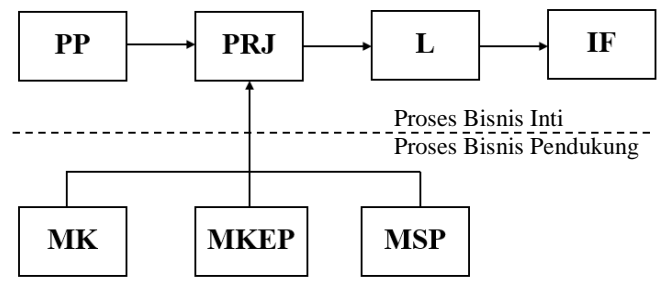

Gambar 2. Hirarki Fungsi Bisnis

Stakeholder yang berhubungan dengan sistem yang akan dibangin adalah manajer, pimpinan klinik, dokter, karyawan dan pasien. Mekanisme hubungan antara sistem informasi yang akan dibangun dengan stakeholder dapat dilihat pada Tabel 3.

Tabel 3. Mekanisme Hubungan Sistem Informasi dengan Stakeholder

\begin{tabular}{cll}
\hline No. & Stakeholder & Mekanisme Hubungan \\
\hline 1. & Manajer & - Penggerak pelaksanaan manajemen klinik \\
& & - Perencanaan pengadaan obat dan logistik \\
2. & Pimpinan Klinik & - Pembuat keputusan. \\
& & - Keinginan sistem informasi klinik yang akan dibangun. \\
3. & Dokter & - Pengguna sistem informasi klinik. \\
& & - Pengguna sistem informasi klinik \\
4. $\quad$ Karyawan/Staff & - Pendataan rekam medis. \\
5. Pasien &
\end{tabular}

\subsection{Architecture Data}

Arsitektur data bertujuan mengidentifikasi kebutuhan enterprise terhadap data yang mendukung fungsi bisnis. Arsitektur data menggambarkan seluruh entitas data yang akan dihasilkan, dikelola dan digunakan oleh semua fungsi atau proses bisnis. Pada tahap ini akan dibuat daftar semua usulan entitas data berdasarkan fungsi bisnis yang telah didefinisikan sebelumnya. Daftar usulan entitas beserta definisinya akan dijelaskan pada Tabel 4 dibawah ini. 
Tabel 4. Daftar Usulan Entitas Data

\begin{tabular}{|c|c|c|c|}
\hline No. & Kandidat Modul & Keterangan & \\
\hline 1. & $\begin{array}{l}\text { Modul } \\
\text { Pendaftaran } \\
\text { Pasien }\end{array}$ & $\begin{array}{l}\text { Admin_Pendaftaran } \\
\text { Calon_pasien } \\
\text { Data_diri_pasien } \\
\text { No_antrian } \\
\text { Rekam_medis } \\
\text { Dokter } \\
\text { Poli } \\
\text { Laporan }\end{array}$ & $\begin{array}{l}\text { Mendaftarkan pasien dan Mengarahkan pasien ke poli } \\
\text { yang dituju. } \\
\text { Memberikan informasi tentang data identitas pasien. } \\
\text { Pengolahan data diri pasien seperti nama, jenis kelamin, } \\
\text { umur, tanggal lahir, alamat } \\
\text { Nomor tunggu antrian pasien } \\
\text { Data rekam medis keluhan pasien } \\
\text { Data dokter yang menangani pasien } \\
\text { Poli tujuan pasien sesuai keluhan } \\
\text { Laporan akhir dari pendaftaran pasien }\end{array}$ \\
\hline 2. & $\begin{array}{l}\text { Modul Poli Rawat } \\
\text { Jalan }\end{array}$ & $\begin{array}{l}\text { Petugas } \\
\text { Pasien } \\
\text { Dokter } \\
\text { Poli } \\
\text { Rekam_medis } \\
\text { Resep_obat } \\
\text { Laporan }\end{array}$ & $\begin{array}{l}\text { Mengarahkan pasien ke poli tujuan } \\
\text { Memberikan informasi tentang keluhan } \\
\text { Penginputan data rekam medis pasien } \\
\text { Poli tujuan pasien sesuai keluhan } \\
\text { Data rekam medis keluhan pasien } \\
\text { Data resep oabt yang di tulis oleh dokter sesuai } \\
\text { kebutuhan pasien } \\
\text { Laporan akhir dari poli rawat jalan }\end{array}$ \\
\hline 3. & $\begin{array}{l}\text { Modul } \\
\text { Laboratorium }\end{array}$ & $\begin{array}{l}\text { Analis_labor } \\
\text { Dokter } \\
\text { Pasien } \\
\text { Blanko } \\
\text { Hasil_laboratorium } \\
\text { Laporan }\end{array}$ & $\begin{array}{l}\text { Menerima blanko permintaan } \\
\text { Data dokter yang bersangkutan } \\
\text { Memberikan informasi tentang keluhan } \\
\text { Formulir permintaan } \\
\text { Data hasil dari pemeriksaan } \\
\text { Laporan akhir dari laboratorium }\end{array}$ \\
\hline 4. & $\begin{array}{l}\text { Modul } \\
\text { Instalasi Farmasi }\end{array}$ & $\begin{array}{l}\text { Apoteker } \\
\text { Dokter } \\
\text { Pasien } \\
\text { Resep_obat } \\
\text { Jenis_obat } \\
\text { Pemasok_obat } \\
\text { Detail_obat } \\
\text { Laporan }\end{array}$ & $\begin{array}{l}\text { Petugas yang bertanggung jawab dalam pengelolaan } \\
\text { apotek. } \\
\text { Data dokter yang bersangkutan } \\
\text { Data diri pasien yang menerima obat } \\
\text { Penginputan resep obat oleh dokter } \\
\text { Data jenis obat apa saja yang tersedia } \\
\text { Pengolahan data distributor obat (PBF). } \\
\text { Data-data obat seperti nama obat, jumlah obat, stok obat } \\
\text { Laporan akhir dari instalasi farmasi }\end{array}$ \\
\hline 5. & $\begin{array}{l}\text { Modul } \\
\text { Manajemen } \\
\text { Keuangan }\end{array}$ & $\begin{array}{l}\text { Petugas } \\
\text { Biaya_sarana_prasar } \\
\text { ana } \\
\text { Biaya gaji } \\
\text { Biaya_obat } \\
\text { Laporan }\end{array}$ & $\begin{array}{l}\text { Petugas yang mengolah data keuangan } \\
\text { Data biaya sarana \& prasarana } \\
\text { Data biaya gaji karyawan } \\
\text { Data biaya obat } \\
\text { Laporan akhir dari manajemen keuangan }\end{array}$ \\
\hline 6. & $\begin{array}{l}\text { Modul Manajemen } \\
\text { Kepegawaian }\end{array}$ & $\begin{array}{l}\text { Petugas } \\
\text { Absensi } \\
\text { Jadwal_shift } \\
\text { Laporan }\end{array}$ & $\begin{array}{l}\text { Petugas yang mengolah data kepegawaian } \\
\text { Pengolahan data absensi pegawai } \\
\text { Pengolahan data jadwal kerja dokter dan paramedis. } \\
\text { Laporan akhir dari manajemen kepegawaian }\end{array}$ \\
\hline 7. & $\begin{array}{l}\text { Modul Sarana \& } \\
\text { Prasarana }\end{array}$ & $\begin{array}{l}\text { Petugas } \\
\text { Sarana_prasarana } \\
\text { Pembaharuan_sarana } \\
\text { _prasarana } \\
\text { Laporan }\end{array}$ & $\begin{array}{l}\text { Petugas yang mengolah data sarana \& prasarana } \\
\text { Data sarana \& prasarana yang tersedia } \\
\text { Data pembaharuan sarana \& prasarana } \\
\text { Laporan akhir dari manajemen sarana \& prasarana }\end{array}$ \\
\hline
\end{tabular}

\subsection{Application Architecture}

Arsitektur aplikasi dibangun untuk mengidentifikasi aplikasi-aplikasi utama yang dibutuhkan oleh enterprise dalam mengelola data serta mendukung fungsi bisnis. Arsitektur aplikasi diidentifikasi berdasarkan kebutuhan informasi yang mendukung pengambilan keputusan dan pertukaran informasi antar tiap fungsi bisnis. Arsitektur aplikasi dibangun berdasarkan arsitektur data yang telah dibangun serta fungsi bisnis yang telah ditetapkan sebelumnya. Tabel 5 merupakan daftar usulan aplikasi pada Klinik Inti Sehat Medika. 
Tabel 5. Daftar Usulan Aplikasi

\begin{tabular}{|c|c|c|c|c|}
\hline No & Fungsi Bisnis & Sistem Informasi & Kode Aplikasi & Daftar Aplikasi usulan \\
\hline \multirow[t]{3}{*}{1} & Pendaftaran Pasien & Sistem Informasi & AP-1.1 & Aplikasi pendaftaran pasien \\
\hline & & Pendaftaran & AP-1.2 & Aplikasi nomor antiran \\
\hline & & Pasien & AP-1.3 & Aplikasi jadwal dokter \\
\hline \multirow[t]{2}{*}{2} & Poli Rawat Jalan & Sistem Informasi & $\mathrm{AP}-2.1$ & Aplikasi pencatatan pasien \\
\hline & & Rawat Jalan & AP- 2.2 & Aplikasi Data Rekam Medis \\
\hline \multirow[t]{3}{*}{3.} & Laboratorium & Sistem Informasi & AP-3.1 & Aplikasi blanko \\
\hline & & Laboratorium & AP-3.2 & Aplikasi pencatatan hasil laboratorium \\
\hline & & & AP-3.3 & $\begin{array}{l}\text { Aplikasi pengarsipan data hasil } \\
\text { laboratorium }\end{array}$ \\
\hline \multirow[t]{4}{*}{4.} & Instalasi Farmasi & Sistem Informasi & $\mathrm{AP}-4.1$ & Aplikasi resep obat \\
\hline & & Instalasi Farmasi & AP -4.2 & Aplikasi Obat Masuk-Keluar \\
\hline & & & AP-4.3 & Aplikasi persedian stock obat \\
\hline & & & AP-4.4 & Aplikasi pelaporan obat \\
\hline \multirow[t]{5}{*}{5} & $\begin{array}{l}\text { Manajemen } \\
\text { Keuangan }\end{array}$ & $\begin{array}{l}\text { Sistem Informasi } \\
\text { Manajemen }\end{array}$ & AP-5.1 & $\begin{array}{l}\text { Aplikasi pengolahan biaya sarana \& } \\
\text { prasarana }\end{array}$ \\
\hline & & Keuangan & AP-5.2 & Aplikasi pengolahan Aplikasi \\
\hline & & & & pengolahan biaya obat \\
\hline & & & AP-5.3 & Aplikasi Penggajian \\
\hline & & & AP-5.4 & Aplikasi pelaporan keuangan \\
\hline \multirow[t]{3}{*}{6} & Manajemen & Sistem Informasi & AP-6.1 & Aplikasi Data Pegawai \\
\hline & Kepegawaian & Manajemen & AP-6.2 & Aplikasi jadwal shift \\
\hline & & Kepegawaian & AP-6.3 & Aplikasi evaluasi kinerja petugas \\
\hline \multirow[t]{2}{*}{7} & $\begin{array}{l}\text { Manajemen Sarana } \\
\text { \& Prasarana }\end{array}$ & $\begin{array}{l}\text { Sistem Informasi } \\
\text { Manajemen }\end{array}$ & AP-7.1 & $\begin{array}{l}\text { Aplikasi pengolahan data sarana \& } \\
\text { prasarana }\end{array}$ \\
\hline & & $\begin{array}{l}\text { sarana \& } \\
\text { prasarana }\end{array}$ & AP-7.2 & Aplikasi pelaporan sarana \& prasarana \\
\hline
\end{tabular}

Berdasarkan table 5 dapat dipaparkan bahwa sebanyak 21 aplikasi yang dibutuhkan untuk mengelola data berdasarkan kebutuhan informasi. Maka solusi aplikasi dapat dilihat pada gambar 3 berikut

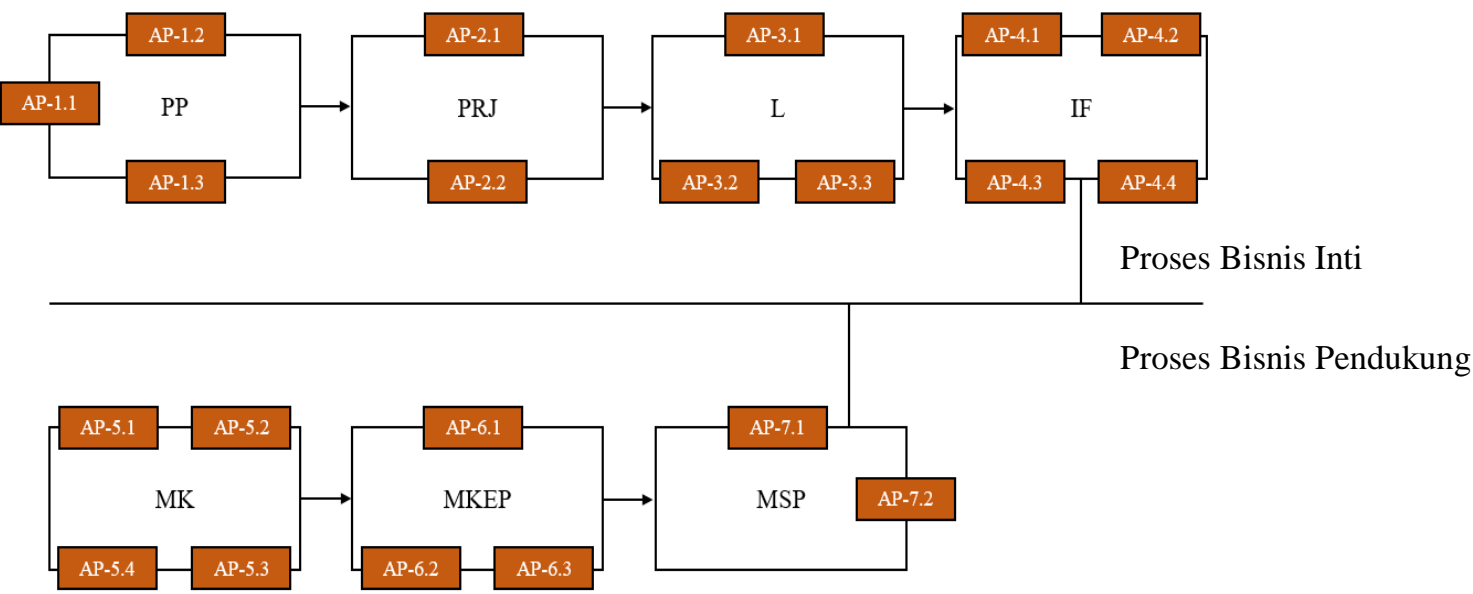

Gambar 3. Solusi Aplikasi

Arsitektur sistem aplikasi dapat dimodelkan menggunakan Application Landscape yang tersaji dalam gambar 4 


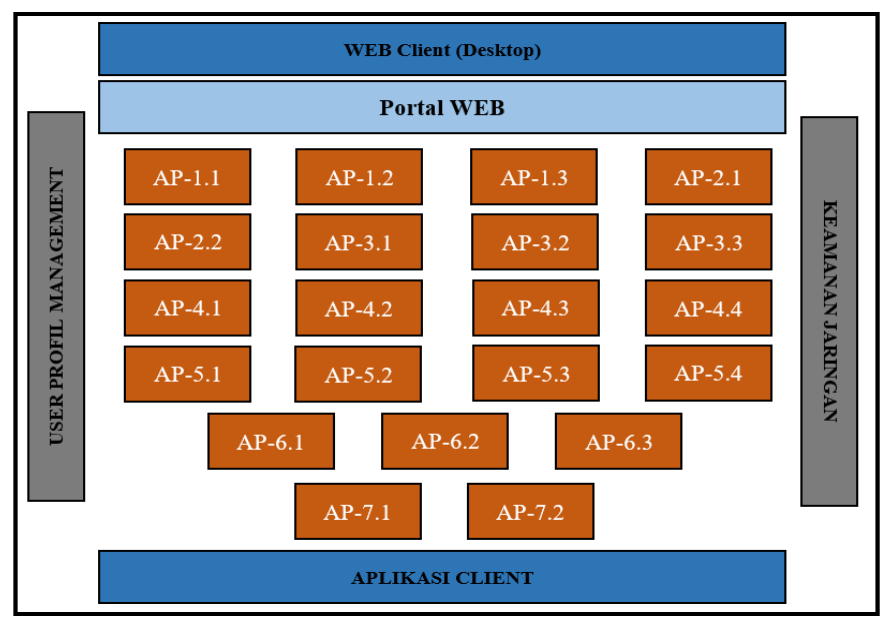

Gambar 4. Application Landscape

\subsection{Technology Architecture}

Tujuan dari arsitektur teknologi adalah untuk menjabarkan jenis-jenis teknologi yang diperlukan bagi aplikasiaplikasi yang telah ditetapkan dari tahap application architecture. Platform aplikasi yang diusulkan direpresentasikan seperti gambar berikut :

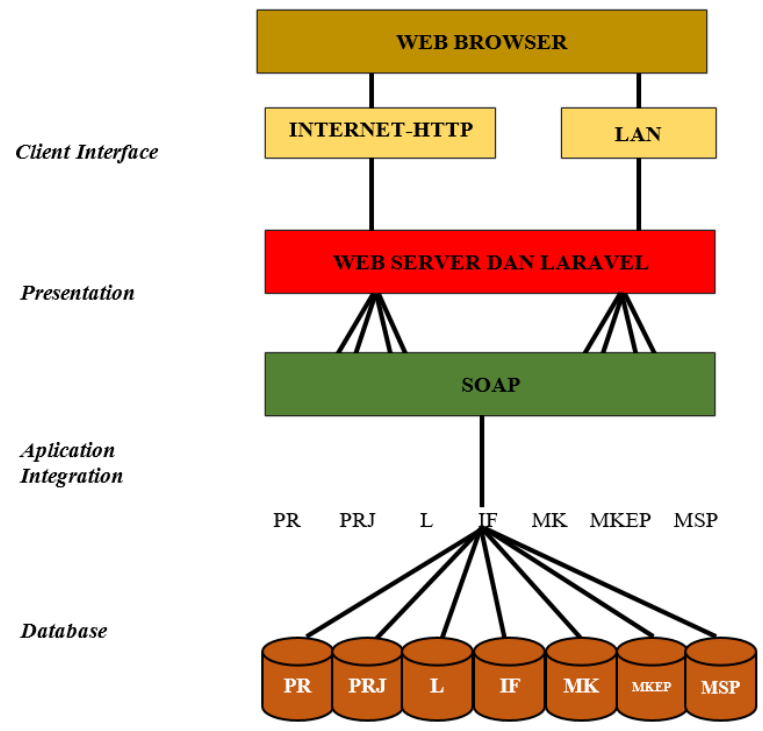

Gambar 5. Platfrom Aplikasi

Layanan jaringan yang akan diberikan berupa LAN, Internet, basis data server, dan aplikasi server. Layanan LAN digunakan untuk berbagi sumber daya seperti printer dan pertukaran data. Internet digunakan untuk akses informasi dan komunikasi. Koneksi ke internet juga dapat digunakan media wireless. Basis data server digunakan sebagai penyimpanan dan pengolahan data PR, PRJ, L, IF, MK, MKEP, MSP. Aplikasi server dialokasikan untuk kepentingan penyimpanan aplikasi yang diperlukan sebanyak 21 aplikasi yang telah dijelaskan sebelumnya pada tabel 3. Rancangan topologi jaringan Klinik Inti Sehat Medika dapat dilihat pada Gambar 6. 


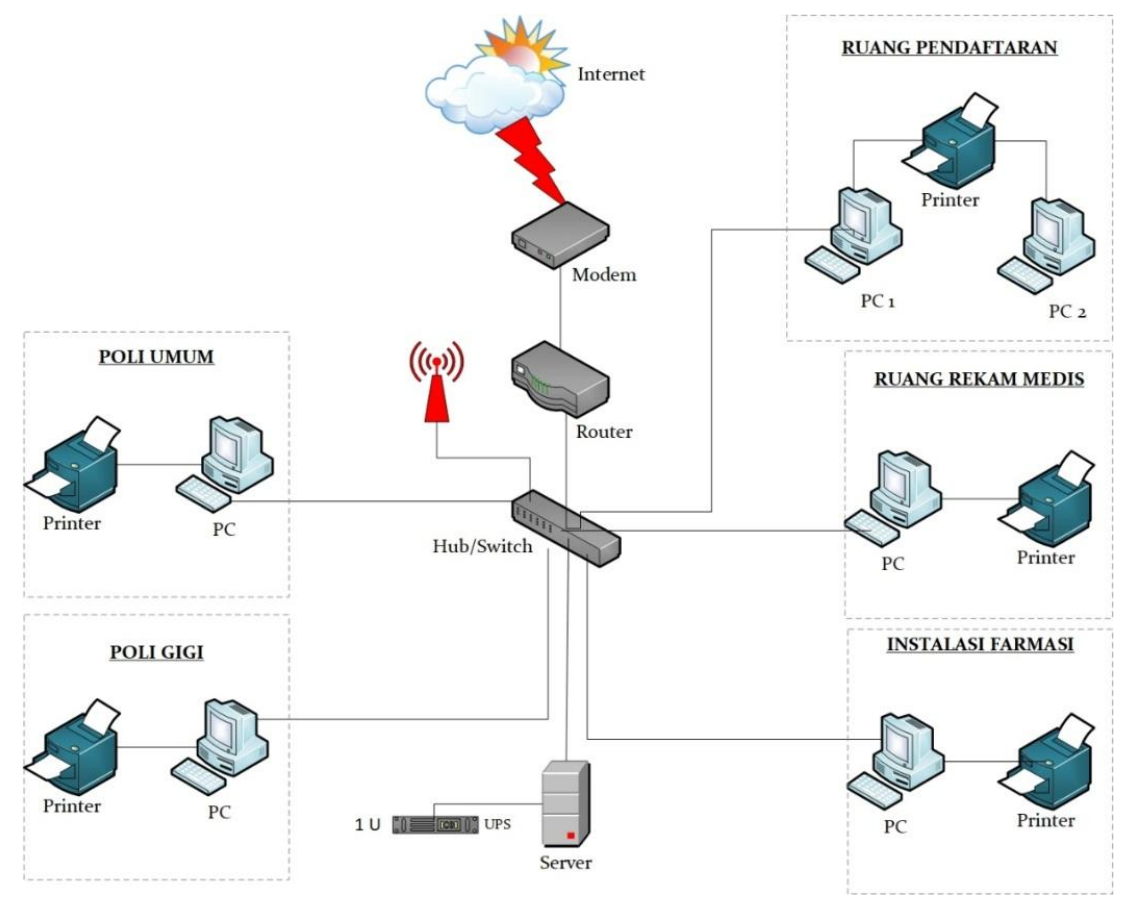

Gambar 6 Topologi Jaringan

\section{Kesimpulan}

Penelitian ini menghasilkan blueprint arsitektur enterprise bagi Klinik Inti Sehat Medika menggunakan TOGAF ADM, yang meliputi arsitektur visi, arsitektur bisnis, arsitektur sistem informasi, dan arsitektur teknologi. Sebanyak 7 entitas bisnis, 25 entitas data dan 21 aplikasi terintegrasi yang dikembangkan dengan dukungan layanan jaringan yang memadai, sehingga dapat menunjang kebutuhan organisasi di masa mendatang.

\section{Daftar Pustaka.}

[1] A. Dennis, B. H. Wixom, and R. M. Roth, System Analysis And Design, Fifth Edit. USA: John Wiley \& Sons, 2012.

[2] B. Van Gils and S. Van Dijk, The Practice of Enterprise Architecture : Experiences, techniques, and best practices. BiZZdesign, 2014.

[3] R. P. Siwi, R. Saedudin, and R. Hanafi, "Perancangan Enterprise Architecture Pada Fungsi Kesehatan Masyarakat Di Dinas Kesehatan Kabupaten Bandung Menggunakan TOGAF ADM," $J$. Rekayasa Sist. dan Ind., vol. 3, no. 4, pp. 82-90, 2016.

[4] A. H. Fikri, W. Purnomo, and W. H. N. Putra, "Perancangan Enterprise Architecture Menggunakan TOGAF ADM pada PT. Hafintech Prima Mandiri," J. Pengemb. Teknol. Inf. dan Ilmu Komput., vol. 4, no. 7, pp. 2032-2042, 2020.

[5] E. B. Setiawan, "Pemilihan EA Framework," Semin. Nas. Apl. Teknol. Inf., vol. 2009, no. SNATI, pp. 114-119, 2009.

[6] Prawira, E. N. Azizah, and D. Astuti, "Perencanaan Arsitektur Enterprise Menggunakan Metode Togaf ADM Pada Puskesmas Mempawah,” in Seminar Nasional Sistem Informasi dan Teknologi Informasi 2018, 2018, pp. 87-91.

[7] A. Guntara, "Perancangan Arsitektur Sistem Informasi Enterprise Pada Puskesmas Kecamatan Cimalaka Kabupaten Sumedang," J. Ilmu-ilmu Inform. dan Manaj. STMIK Sumedang, vol. 10, no. November, pp. 1-10, 2016.

[8] W. Saputra, A. Nani, and L. Andini, "Enterprise Architecture Planning Sistem Informasi Puskesmas Siantan Hilir," in SENSITEK, 2018, pp. 465-469.

[9] D. Angeline and C. Fibriani, "Perencanaan Arsitektur Enterprise Menggunakan TOGAF ADM (Studi Kasus: Kantor Desa Lembang),” J. Inf. Syst. Informatics, vol. 3, no. 2, pp. 456-466, 2021.

[10] J. J. Djumoko and A. D. Manuputty, "Perencanaan Arsitektur Enterprise Di Language Training Center- UKSW Menggunakan Framework TOGAF ADM," J. Tek. Inform. dan Sist. Inf., vol. 8, no. 1, pp. 225-236, 2021. 